\title{
O CURSO DA ÁGUA NA CIDADE DE GUARAPUAVA: MEMÓRIA E REPRESENTAÇÃO SOCIAL ${ }^{1}$
}

\section{Beatriz Fagundes ${ }^{2}$}

O avanço da urbanização, uma das maiores transformações do espaço na atualidade, tem causado alto grau de degradação no meio natural e, em especial, para as águas. Como ambiente artificial por excelência, fatores naturais, como o verde, os animais, a água e outros elementos têm sido gradativamente expulsos ou transformados durante este processo civilizatório. Considerando esta situação, o presente estudo pretende abordar como as relações dos moradores de Guarapuava, PR, com os seus rios e outras águas, têm se modificado durante o processo da produção do espaço urbano. Estas relações se referem tanto a organização da água no espaço urbano (canalização, encanamento, desaparecimento) como ao uso deste recurso nas práticas sociais (água potável, esgoto, uso para lazer etc). Como cada ação para com o ambiente é acompanhada por reflexões dos moradores da cidade, a água, em especial os rios no espaço urbano, aparece também como uma representação social. Esta abordagem permite revelar como a relação ambiental (ou não) dos moradores reflete-se na mudança de atitudes, de necessidades, de conhecimentos e até de etnofilosofias. Com este trabalho esperamos, assim, entender o processo pelo qual Guarapuava e a sua população se sobrepunha à paisagem até então natural, tanto em termos materiais quanto simbólicos, na esperança de poder proteger o que ainda existe dessa paisagem e oferecer uma melhor qualidade de vida para a população.

PALAVRAS-CHAVE: rio; cidade; representação.

\footnotetext{
${ }^{1}$ Orientador: Prof. Dr. Wolf Dietrich Sahr

${ }^{2}$ Mestranda em Geografia (UFPR) - e-mail: beafagundes@yahoo.com.br
} 